\title{
Fiestas reales en el Setecientos en Canarias. Identidades, evolución y peculiaridades
}

\author{
Antonio de Béthencourt Massieu*
}

\begin{abstract}
RESUMEN ABSTRACT
Análisis comparativo de las relaciones festivas por el nacimiento del Príncipe Luis (1707) y proclamación de Carlos III (1760) de los historiadores Pedro Agustín del Castillo y José Viera y

Clavijo. Del mismo se derivan identidad entre las celebradas en Canarias y en la Península, evolución coyuntural a lo largo del Setecientos y

las muchas peculiaridades de las insulares.

A comparative analysis of two accounts on the festivals held to commemorate Prince Luis' birth (1707) and Charles III's proclamation (1760), written by Pedro Agustín del Castillo and José Viera y Clavijo. It permits to grasp the identity of the festivals that took place in the Canary Islands and in continental Spain, the evolution along the eighteenth century and the many singular features in those held in the Islands.
\end{abstract}

La obligación [del Príncipe] es, además ocuparse de las fiestas y espectáculos en aquel tiempo del arte, en que conviene que las haya.

(N. Maquiavelo)

\section{PLANTEAMIENTO}

No es objeto de la presente contribución realizar un análisis sobre la abundante historiografía sobre las fiestas reales en España. Y menos profundizar sobre la concepción y significado de las mismas. En otros trabajos

* Catedrático emérito. Departamento de Historia Medieval y Moderna. UNED. 
de este número monográfico de Espacio. Tiempo y Forma encontrará el lector referencias y novedosas aportaciones.

Me reduciré a tema más modesto. Simplemente a describir cómo fueron las fiestas conmemorativas a sucesos reales en Canarias durante el siglo XVIII. Dar noticia de alguno de estos eventos, pero también comprobar en qué medida fueron homogéneas con las celebradas en otras ciudades del reino, cuáles fueron sus matices y cómo evolucionaron a lo largo de la centuria.

Como el espacio concedido es limitado, he preferido sacrificar cantidad a calidad. No haré, por tanto, referencia a todas las celebraciones, sino a las dos que estimo más espectaculares. Espectaculares por su contenido, las bien cortadas plumas y alto nivel intelectual de los narradores, que no son ajenos, de otra parte, a la organización de las mismas: Pedro Agustín del Castillo Ruiz de Vergara y José Viera y Clavijo. Ambos excelentes historiadores.

El primero nos legó memoria de los actos festivos por el nacimiento del futuro Luis I' (Láminas I y II) y Viera los de la proclamación de Carlos III ${ }^{2}$ (Láminas III y IV).

Relación diaria de las alegres y lucidas demostraciones conque la muy noble y muy leal Ciudad de Las Palmas y lugares de esta Isla de Gran Canaria celebraron el Felicísimo Nacimiento del Principe N.S. Don Luis, el primer hijo de nuestro legitimo Rey y Señor Don Felipe $V$ y Doña Maria Luisa de Saboya (g. D. g.) (1701). El ms. se conservó en el Archivo del Condado de la Vega Grande de Guadalupe dentro de un libro titulado: Consultas y Papeles a diversos asumptos. Escritos de Ordenes superiores y de oficio. Por D. Pedro Agustín del Castillo Ruiz de Vergara, etc. Portada reproducida por MIl.LARES CAALO, A. en su Bibliografia de Escritores de las Islas Canarias (siglos Xvi, Xvil y xvili). Las Palmas de G.C.- Mancomunidad de Las Palmas, 1977. Tm. II, págs. 228 y 229. Desgraciadamente hoy perdido. Afortunadamente las Consultas y Papeles fueron transcritos por Millares Torfies, A. y se conservan en El Museo Canario (E.M.C.), bajo el título Obras diversas de D. Pedro Agustin del Castillo Ruiz de Vergara, etc. La Relación, págs. 35 va a $40 v^{\circ}$, fue publicada en la Revista E.M.C., III (1981), 363- 370; IV (1981-1982), 11-15, 47-50, 75-78. 208-211. 239-247 y 272-277. Preparo la edición de las Consultas y Papeles.

Compendiosa noticia de las cordiales demostraciones, con que se celebró la traslación a Catholico Monarca de las Españas y de las Indias nuestro actual y muy amado Rey Don Carlos III (Que Dios Guarde). La Muy Noble y Leal Ciudad de San Christobal de La Laguna, una de las Canarias, en su Proclamación y regocijos en los tres primeros dias de junio del corriente año de 1760. Santa Cruz de Tenerife (S.C.T.).- Imprenta Real de Guerra y Marina, en la calle del Sal [1760]. Texto publicado en ed. facsímil: Viera y Clavino, J., Fiestas que la Ciudad de San Christobal de La Laguna celebró en 1760 por la proclamación del Rey Carlos III. Introd. y notas de RomeU [PALAzUELOS], E., S.C.T..- R.S.E.AA. del PP. de Tenerife, 1986, 48 págs. Precede al texto, reproducción de "El Jardin de las Hespérides", 3 págs. Es un curioso antecedente de un programa de mano explicativo de la alegoría de la carroza y cortejo del segundo día. Viera se ocupó de los disfraces, de la representación alegórica de los carros, de los textos en latín y español con que se adornaron los templos, etc. Lo explicita asi el autor en su Autobiografia. Romeu Palazuelos, cit., págs. 21-23.

Cfr. Gallardo Peña, M., "Fiestas de exaltación al trono y cuadros de Carlos III en La Laguna". En E.M.C. LI (1996), 271-273. Y otro de igual título para la proclamación de Carlos IV en Anuario de Estudios Atlánticos (A.E.A.), 41(1995), págs. 271-285. 


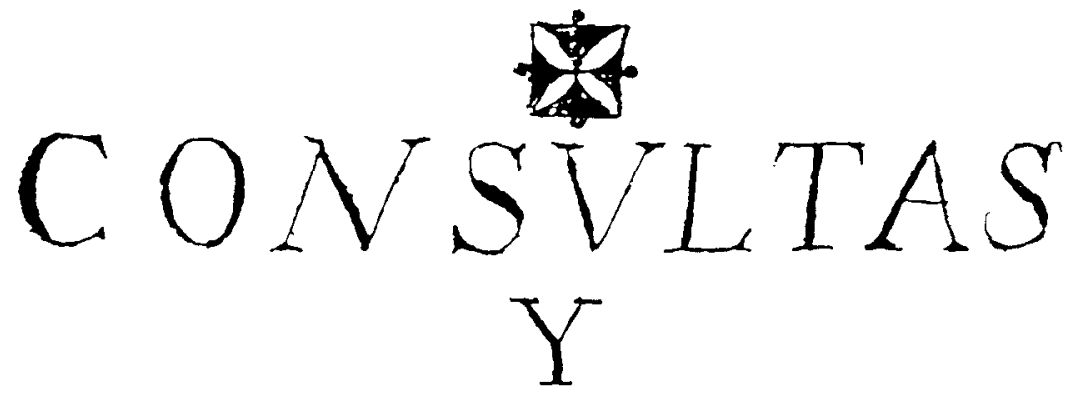

PAPELES. ÄDIVERSOS ASSWPT: ESCRIPTOS

DE ORDENES SVPERIORES YDEOficio.

\section{POR D. PEDRo Avgrstiv DEL CASTILLO} Rviz de VERGARA SEXTO AlFEREz Hu. YOR HRREDITARIO DE LA YSLA DF GR̂̀ CANARJA Y DECANO PERPETVO DE sV CiVDAD Y Recimineto.

Lámina I. Portada del manuscrito de Pedro Agustín del Castillo que contenía la "Relación" de 1707.

El nacimiento de Luis, en los inicios de la centuria; la segunda, rebasado el ecuador de la misma. Aquella ajustada al tradicional modelo del Barroco, ésta con caracteres propios de la incipiente llustración reformista. La felipina agraria y urbana, la carlostercerista ciudadana en exclusiva. La 


\section{Relacione}

distia delar alegte, staviday derrew-

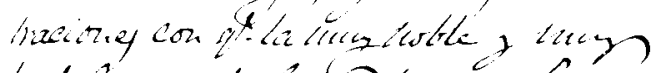

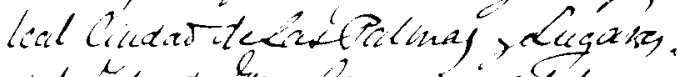

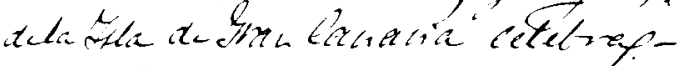

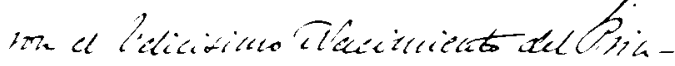

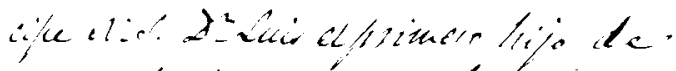

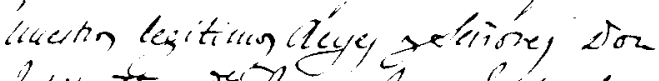

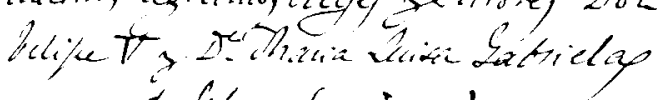

$$
\begin{gathered}
\text { deaboue (g.J.g.) } \\
(1707)
\end{gathered}
$$

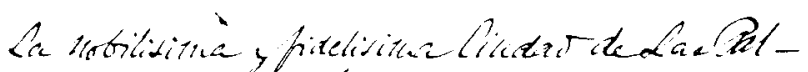

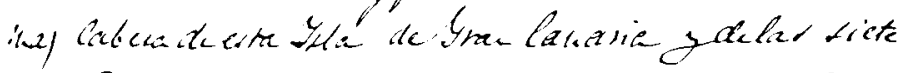

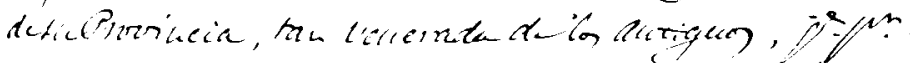

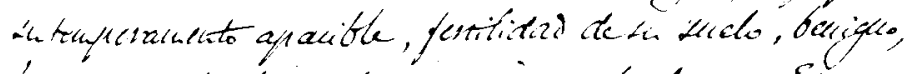

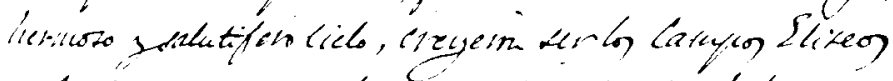

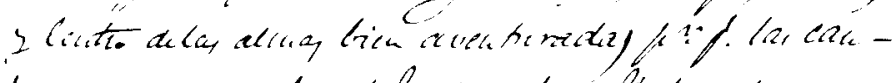

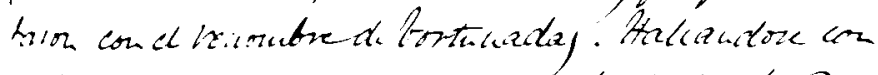

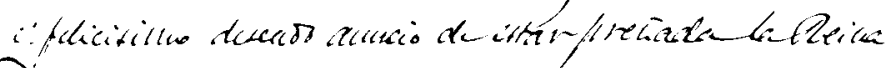

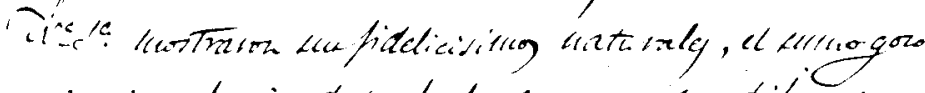

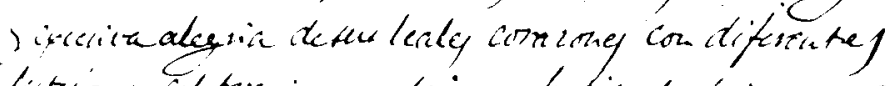

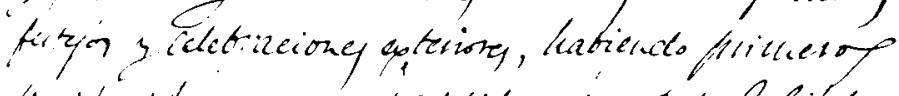

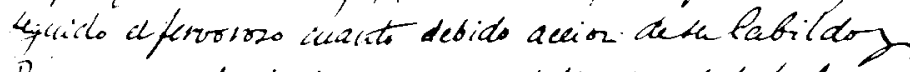

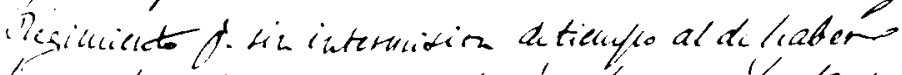

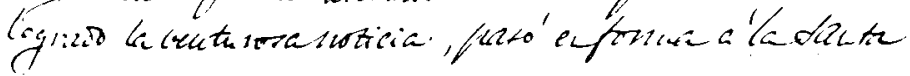

Lámina Il. Portada de la «Relación» de 1707, copiada por Millares Torres en libro que titula Obras varias de Pedro Agustín del Castillo. 


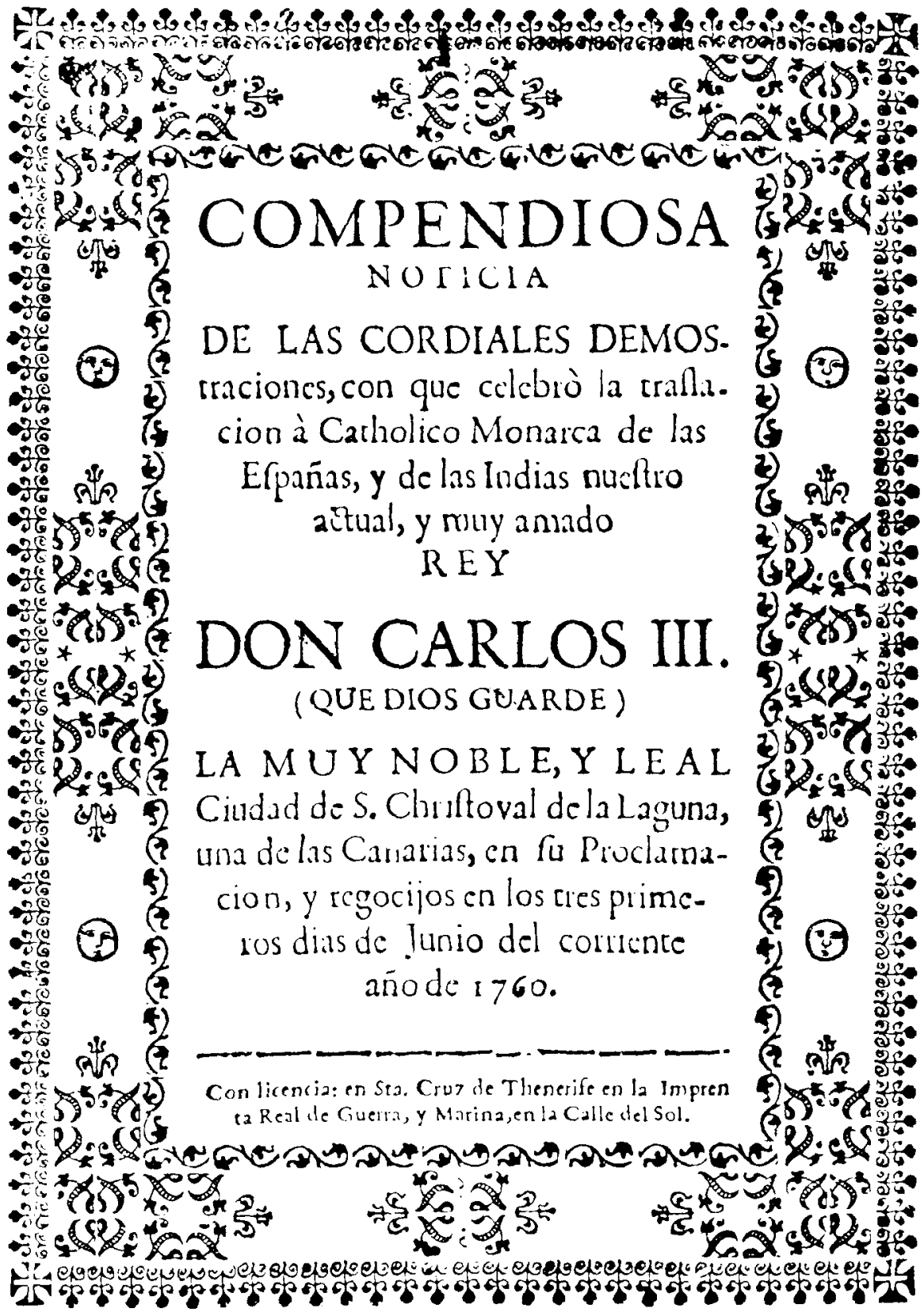

Lámina III. Proclamación de Carlos III por José Viera y Clavijo en La Laguna. 
1

\section{EL F ARDIN DE LAS HESTERIDAS.}

REPRESENTACION ALEGORICA DE LAS ISLAS Canarias, proclamando, y reconocicudo por fu Rey, y Señor à nueltio Cutholico Monaica

\section{DON CARLOSIII.}

(que Dios guarde.)

Difpuefta por los leales Gremius, que llenos de amor, 7 Gidelidad coltean la regunda noche, de las eres que la Mui Noble, y Mui Lal Ciudad de la Luguna, ha delti. nado para celcbiar la Exalacion al Trono de Sinag.

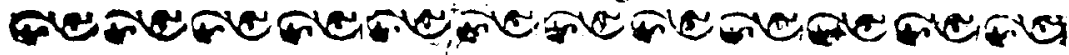

Culara la brigada Un carricocihe a lo J ridiculo ocupado por of Dios Momo ha jo de la noche, y el Sueño con malsara de vicis anui buriona, bitba largas corcoba, baculo con vexigas, y velidura estravagante.

\section{Lc iràn hacicodo consiriva.}

Dos A madrides en trage de Ninfas del báque, veitidas de verife, careras toltadas, corona de artaylan, y arcie, y thech. A compuñadas de dos Satyrosatótradós en ciprès con malcarilia lia, orelas puntiagadas, dos pequeños cucrnos, que fe dijuran ver for las givie. maldas de hojas verdes que llevaran con la caveza y al hombro arco, y aljaba.

Dos Driades veftidas de blanco manchadas de murfor, grcĩa verde, cara bonitilla, y caña en la mano, A compuñudas de ous Fanos medio defnudos, crior tollado, calz',nss, y lavilias de pisles, lsenza verde, y un brazado de hicrra.

Dos

Lámina IV. Programa de mano de Viera y Clavijo sobre la cabalgata alegórica de los Gremios, 1760. 
Fiestas reales en el Setecientos en Canarias. Identidades, evolución y...

primera una de larguísima duración en tiempos de guerra, la otra reducida a tres jornadas gozando aún de la paz fernandina ${ }^{3}$.

\section{Los autores}

El primero, Pedro Agustín del Castillo Ruiz de Vergara ${ }^{4}$ nació y murió en Las Palmas (1669-1741). Miembro de una de las más ricas familias de la élite insular. Castellano del Puerto de La Luz, IV alférez mayor, regidor decano y corregidor interno en 1701 y 1733. De cultura enciclopédica, jurisperto y destacado historiador. Matemático y poliorceta (costeó y fabricó la batería de San Felipe). Su sapiencia y mesura le convirtieron en consejero insustituible en asuntos de gobierno, como asevera Viera y Clavijo ${ }^{5}$. Con dieciocho años redacta y dibuja para el Capitán General una Descripción de las Yslas de Canaria ${ }^{6}$ y una Historia de las Islas que remata en 1737. Comenzó a reunir materiales en $1689^{7}$. Destaca el tratamiento de los aborígenes, novedosas aportaciones y concepción historiográfica. Prosa clara y elegante junto con su capacidad de análisis, son anuncio de la visión ilustrada y enciclopedista de Viera.

José Viera y Clavijo ${ }^{8}$ nació en Realejo Alto y falleció en Las Palmas (1731-1813). De familia campesina acomodada, su padre fue escribano público. Pasó la niñez en el Puerto de la Cruz. Estudió en el convento dominico de La Orotava. En 1752 se ordena sacerdote en Las Palmas. Siente temprana vocación por la lectura. Escribe su primera obra: una novela picaresca. Deslumbrado por Feijóo abandona el escolasticismo. En 1756 se instala en La Laguna y se integra en la tertulia de Nava, o sea la reunida en casa del marqués de Villanueva del Prado, dueño de una prodigiosa biblioteca.

Del 15 de septiembre al 22 de octubre de 1707 frente al 1-3 de junio de 1760

Bibliografia sobre el personaje, en Berhencouri Massieu. A., Pedro Agustín del Castillo. Su vida y su obra. L.P.G.C.- Ed. Cabildo Insular de Gran Canaria (C.I.), 1994.

Colección de informes que encierra el ms. Obras diversas asi lo confirma. Tengo en marcha su publicación.

Ed. facsimil. L.P.G.C., C.I., 1994. Lleva mapas de las Islas, planos de las ciudades y fortalezas bellísimas, sobre todo el de la Ciudad de Las Palmas en visión panorámica. (Lámina V).

Supra nota 4, y la edición critica en 4 vols. de SANTIAGO, M. Madrid, Ed. «El Gabinete Literario" de Las Palmas, 1948-1960.

Blanco MOntesoeoca, J., "Biografía de don José Viera y Clavijo", en Historia de Canarias, 1950. Cioranescu. A. La formación cultural de Viera y Clavijo. La Laguna, 1950. Bethencourt Massieu, A., en la Historia de Canarias de ViegA, Islas Canarias. Biblioteca Básica Canaria, $n^{0} 9$. 1991. 2 vols. Una ajustada sintesis, t. I, págs. 17-31 
Dotado de espíritu crítico, sentido de la ironía y fervoroso de la razón, acabó en ilustrado volteriano aunque fiel a la ortodoxia. Volcado a la docencia, divulgador, auténtico periodista, es hombre de saberes enciclopédicos, traductor y hasta pasable versificador, aunque no alcance alto nivel en el género.

Para imprimir su Historia de Canarias se traslada a Madrid, la de más altura entre las muchas regionales de su siglo. Viajó por Europa: Turín, Roma, Nápoles, Viena, etc. y sobre todo larga estancia en París. Regresa como Arcediano de Fuerteventura, dignidad de Cabildo Catedralicio de Las Palmas.

Según Cioranescu, el más profundo conocedor de su dilatada obra, persiguió la "reunión de todas las ciencias en un sistema capaz de explicarlas, reduciendo después la filosofía a la moral y la sociología". Su amigo el obispo Manuel Verdugo lo define como:

\footnotetext{
«Ese clérigo inquieto y cortesano, que traduce a Voltaire y a Cristo reza...".
}

Es personalidad destacada entre la pléyade de llustrados insulares, a los que reúne en El nuevo Can Mayor o Constelación Canaria del Firmamento Español (1800).

\section{LA LITURGIA}

Contenido y propagación de las relaciones

El origen de las mismas es Italia, como es sabido. En España comienzan a imprimirse desde el siglo xvı. Su redacción se encarga a una pluma bien cortada. Contienen gran lujo de detalles, desde que la orden es recibida, preparativos, espacios festivos, protagonistas, actos que se suceden, etc. Recojen la totalidad, sublimando la realidad de la fiesta.

Es doble su objeto: dar noticia al soberano y la Corte y su impresión para difundir la efeméride, obedeciendo "el mimetismo en los comportamientos y ritualización de los actos" ${ }^{9}$. Y al tiempo subrayar el protagonismo de la institución que acomete la empresa, mérito de su servicio, fideli-

\footnotetext{
9 Monteagudo Robledo, M. P.. La Monarquia ideal. Imagen de la realeza en la Valencia Moderna. Valencia.- Dep. de Historia Moderna, 1995; pág. 45 y "La ciudad en su dimensión festiva". en Historia Social, 26 (1996), págs. 47-62.
} 
dad a la monarquía y orgullo del deber cumplido. Finalmente, difusión "de actos de propaganda" impulsados desde el centro del poder, a los que contribuyen los miembros de la élite local durante sus viajes, sobre todo a la Corte ${ }^{10}$.

Lo afirmado explica que asi como la relación de Viera en 1760 viera la luz, pues Tenerife contaba con la primera imprenta ${ }^{11}$, la de Castillo permaneciera inédita hasta avanzado el siglo $x \mathrm{Ix}^{12}$. Sin embargo, con la remisión de la misma al Rey, 6-X1-1707, se pretende informar a Felipe V, con la esperanza de que fuera impresa en la Corte. Pero, las circunstancias bélicas lo impidieron.

En las relaciones, como las mismas fiestas, no faltan elementos humorísticos, incluso jocosos, bien en las explicitaciones argumentales o como reflejo de manifestaciones populares. Aspectos que no faltan en las relaciones que estudiamos ${ }^{13}$.

\section{La monarquía ideal y su política}

No entraré, como advertí, en disquisiones sobre el concepto de Monarquia, pues las dos relaciones objeto de estudio coinciden en cuanto con tanto acierto explicita la profesora Monteagudo ${ }^{14}$. Sin embargo, estimo necesario subrayar la evolución de la concepción de la institución y las aspiraciones políticas que reflejan autores tan diferentes como Castillo y Viera ${ }^{15}$.

Mientras la de 1707 alude al "servicio a ambas majestades", o sea el Rey como representante de Dios para conducir al pueblo - con olvido de la doctrina neotomista salmantina: cesión de la soberanía por el pueblo al monarca-, Viera omite cualquier tipo de referencia conceptual y sólo deja traslucir una fidelidad homogénea hacia Fernando VI y su sucesor. Por tanto, una posición todavía ambigua (1760) que con los años evoluciona-

\footnotetext{
Maruri Vil lanueva, R., "Contribución al análisis de las fiestas barrocas en la periferia. La celebración en Santader del nacimiento de Luis l", en Homenaje a Antonio de Béthencourt Massieu. L.P.G.C., C.I., 1995, t. II, págs. 437-462, 459.

Sobre Pedro José Pablo Diaz, primer impresor en Canarias, VizCay CarpentieR, A.. Tipo gratia canaria. S.C.T., 1964, XVIH-XIX.

Cfr. supra nota 1

Vie.ra en las palabras introductoilas al Jardin de las Hespérides, ya cit. o Castll. lo en las descripciones de las mojigangas, 17.9 y 23.10.707, entre otras, págs. 23, 24 y 25.

14 Monteagudo, op. cit., cap. II "Fundamentos de la política real" e inicios del III. "Imagen del Rey", págs. $43-74$ y 75 y ss

Supra nota 4
} 
rá en Viera a una ardiente fe en el Despotismo llustrado, acentuada con una estancia en la Corte.

Evolución que no es de extrañar, pues la celebración por el natalicio fue esencialmente barroca, sensibilidad que en las Islas, como en el resto del reino, se prolongó hasta superar el ecuador de la centuria ${ }^{16}$. Dando paso al monarca "como navío principal» del reino, tutor, pastor, arquitecto y padre que conduce a sus vasallos a la consecución del bien común y felicidad basada en la riqueza material. Posición que deja entrever Viera con el Jardín de las Hespérides, y con más diafanidad Bartolomé Benítez de Ponte y Lugo con la relación de las fiestas conmemorativas en la proclamación de Carlos IV en La Laguna ${ }^{17}$.

En efecto, Viera en un cartel, califica a Carlos III de Rex pius, atque pastor, Rex bonus, Rex clemens ${ }^{18}$, adornado de las virtudes teologales y cardinales ${ }^{19}$.

Si bien en ambas celebraciones hay muestras de aspirar a lograr 0 conservar la paz, la de 1707 muestra una optimista esperanza de la aceptación de Felipe $V$ como activo combatiente, en contraste con la triste figura de su antecesor. Vaticinan el triunfo sobre sus enemigos ${ }^{20}$, con la esperanza de no sólo conservar la integridad de la monarquía ${ }^{21}$, insinuando el carácter de guerra civil y religiosa de la contienda ${ }^{22}$, a fin de recuperar la hegemonía. Es más, el nacimiento del Príncipe asegura con numerosa prole en el futuro y es titulado Delfín como heredero factible del Reino de

is Así lo afirma la doctora Montelongo: en plena Guerra de Sucesión Felipe $V$ sólo habia introducido escasas reformas, como la restructuración de la autoridad real, de una parte: de otra, porque, amén de las nuevas directrices, la via hacia la llustración y sus consecuencias conceptuales sobre la monarquia, y las retormas tendrian que esperar al portillo del reinado de Fernando VI. Monieagudo, op. cit., pág. 41 y Mestre Sanchis, A., La llustración. Madrid, 1993.

Autores citados y Gallardo PENA, M. «Fiesta de exaltación al trono y retratos de Carlos IV en La Laguna». En A.E.A., 41 (1995), págs. 271-285.

- VIERA, 28. Glosa los dísticos antiguos Gloria Laus. Al pie del retrato de Carlos IV: "In Ca rolo explendet, Rex pius, atque Pater". GALLARDO, art. cit., 11.

"y "Fe. Esperanza y Charidad/ Te conducen al Dosel/ Que Carlos más sabio y fiel/, Es justa la Majestad. „VIEFA, 39-40. Las figuras de Prudencia, Justicia, Fortaleza y Templanza van ilustradas con quintillas. Loc. cit., págs. 38-39.

20 "Publiquen en la Tierra / A unos la paz / A otros la guerra / Arma, arma / Que al son coronado..." Y Luis "Traza la tierra / A más de la dicha / a otros la Guerra... CASTILLO, págs. 28-29. LOS ejemplos podrían multiplicarse.

En un sainete identifica al Imperio con la Vanidad, a Portugal con la Codicia, a las Potencias Marítimas con la Soberbia, que son derrotadas por el Amor que es el Príncipe con las flechas de su carcaj. Op. cit., págs. 29-32.

Jover Zamora, J. M., Atlántico y Mediterráneo en la España de Feijóo. Cuadernos Cátedra Jovellanos. Oviedo, 1956 
Francia. Por tanto, todo un programa político ${ }^{23}$. En contraste, de Carlos se espera un papel "dominante" -no dominador- de Europa, conservador de América y su riqueza, así como de Filipinas en Asia, y en África de los presidios, "turbantes» de "mauritanos y númidas", sin olvidar a Argel como destino ${ }^{24}$.

Los textos que podrían aducirse sobre la fidelidad a la nueva dinastía una vez consolidada, son innumerables ${ }^{25}$. Los más significativos se encuentran en la carta con que Pedro Agustín del Castillo envía su relación al Rey ${ }^{26}$, o el “Apóstrofe a S.M.» con que Viera cierra la suya ${ }^{27}$.

Tampoco escasean, como era habitual, la conceptuación de los monarcas y personas reales identificándolas ${ }^{28}$ con el mundo astral, como sol; animal, como León; vegetal como clavel, lis e iris; mitológico, Cupido o Venus Saboyana; personajes históricos, Alejandro, o bíblicos, Josué, de los que omitimos abundantísimas citas.

\section{Noticia y convocatoria festiva}

En ambos aspectos no hay diferencias con la Península. En nuestro caso no es lo mismo un nacimiento que una proclamación. Al tiempo, la adhesión a una nueva y polémica dinastía con un acto de relevo.

Como en Las Palmas se conoció el embarazo de la reina, hubo rogativas y en agosto una cierta espectativa. El 15 de septiembre se percibieron disparos de artillería desde Tenerife. Se tomaron las medidas defensivas a

\footnotetext{
23 "Aunque León ha nacido / También sabe / Que es Delfín anunciado / ¡Felicidades!". CASTilı 10 , pág. 34

24 Décimas que adornan las cuatro Virtudes a los pies del retrato de Carlos III en la iglesia de la Concepción. VIERA, págs. 36-37.

35 "... en rótulos de letras de fuego mostraban el que ardía en los corazones, de amor a nuestro invícto Monarca y Señor Don Felipe $V$ y el incomparable goze del nacimiento... ". CASTILLO, op. cit., pág. 23.

25 "Dios que ha sido servido de oir nuestras súplicas concediéndonos tan singular beneficio (no sólo para los reales dominios de V.M., sino defensa de su lglesia) conserve duplicados siglos a V.M. con perfecta salud, dilatada sucesión y triunfos de sus enemigos...". CASTHLO, op. cit., pág. 41. Merece un amplio comentario. Encierra la clave de la adhesión de los isleños a la nueva dinastía. Arriesgar recortes en las tranquicias a sufrir el dominio de enemigos tradicionales: ingleses, holandeses y protestantes.

"Sois, Señor, Sol de las Españas. Ya os habiais culminado en los Meridianos de su vasta esphera: pero ahora es quando acabaís de subir a Vuestro primer Meridiano. Tal es en la mejor Cosmographía Thenerife. Lucid en él amado Carlos, repetidisimos lustros...". VIERA, op. cit., pág. 48.

Monte agudo, op. cit. "Alegorias y simbolos reales", págs. 184-194.
} 
causa de la guerra. Pero a la mañana siguiente se confirmó el alumbramiento, en medio de una alegría desbordante. Repiques de campanas, vivas y "unos arrojaron dinero y los otros sombreros" ${ }^{29}$. Te Deum por cuenta del Cabildo y luminarias nocturnas. Se organiza el calendario festivo, a clausurar el 23 de octubre, un mes y una semana, invitando a autoridades y pueblos del interior. Fiestas desencadenantes de auténtica cohesión social, aunque con clara separación entre los protagonizados por el pueblo y los poderosos, o sea la élite, caracterizados éstos por su carácter propiamente urbano ${ }^{30}$.

El contraste con la exaltación al trono en Tenerife tiene un doble significado: el cambio de los tiempos — del Barroco a la llustración ${ }^{31}$ - y la diversa coyuntura económica. La pérdida de los mercados del vino a finales del xvII y la escasez de cereales, produjo un largo ciclo de contracción económica que afectó más crudamente a Tenerife que a Gran Canaria ${ }^{32}$. La balanza deficitaria prolongada explica que en ésta a comienzos de siglo circulara aún plata, que en 1760 desaparece en Tenerife ${ }^{33}$.

Si bien el 23 de enero llegan a Santa Cruz las cartas de Isabel Farnesio de 26 y 27 de agosto, ordenando la pronta proclamación de su hijo Carlos -el amado Charlete para su madre - aún sin celebrar las exequias por Fernando VI, el Cabildo lagunero, dado "el infeliz estado a que se había reducido nuestra Isla, la falta de todo género de pan ${ }^{34}$, decide decretar un luto de seis meses por el fallecimiento del soberano y retrasar

CASTILLO, op. cit., págs. 30 y 31.

"... las fiestas son un ejercicio colectivo de hospitalidad. Los signos festivos neutralizan temporalmente las lacras de las territorialidades». VELASCO, H. M., "Las fiestas, drama y tensión". en Diez Borque, J. M. (Coord.), Teatro y fiestas del Barroco. España e Italia. Barcelona, 1986. Lo veremos más adelante.

Maruhi Villanueva, R., op. cit., pág. 462. En Canarias, si comparamos la celebraciones en honor con la proclamación de Carlos IV, observamos la desaparición de obras teatrales, de tanto arraigo popular, aunque se mantengan diálogos entre carretas y personajes. BENITIZ DE PONTE Y Lugo, B., "Plan General y noticias previas a las Reales Fiestas con que...S. Christobal... la proclamación... de Carlos IV. La Laguna. Miguel Ángel Bazzanti, 1785 y Gallardo PenA, M., art sobre la proclamación de Carlos IV ya cit.

Béthencourt Massieu, A. de, Canarias e Inglaterra: el comercio del vino, 1650- 1820. L.P.G.C.: C.1., 1991, $2^{\text {}}$ ed. Y "La crisis del vino de Canarias en el ámbito atlántico", en Canarias e Inglaterra a través de la Historia. L.P.G.C.; C.I., 1995; 69-99. Macías Hernandez, A. M., "La economía moderna (siglos $x v$-xvIII)", en Historia de Canarias. L.P.G.C.; C.1., 1995, 133-192; págs. 168-173.

33 Macias Herinandez, A. M., "Canarias en el proyecto monetario ilustrado". En A.E.A., 38 (1992), págs. 281-336.

${ }_{4}$ VIERA, Op. cit. págs. 14-15. El aislamiento de las Islas con la Corte es manifiesto. En 1760 tarda una carta real cuatro meses en paz, mientras en 1707 y en plena guerra no tarda ni un mes. 
la proclamación hasta los tres primeros días de enero, cuando la cosecha de cereales permitió organizar la celebración con el lujo necesario ${ }^{35}$.

\section{EL ESCENARIO}

\section{Escenario urbano}

Todos los autores coinciden en que la fiesta, tanto en su lado sacro como en el cívico, necesita un escenario urbano. Con palabras de Bonet Correa: "Espacios transformados a noches de fugaces escenografias en pos de la ciudad ideal: las arquitecturas efímeras" ${ }^{36}$.

¿Cuáles fueron los espacios adoptados y transformados en Las Palmas y La Laguna? Lo más sencillo consiste en señalarlos en planos de ambas ciudades. Sin embargo, antes de su inclusión y comentario es conveniente señalar la diferente óptica con que cada autor se enfrenta al marco urbano respectivo. Mientras Castillo se muestra orgulloso de Las Palmas y siguiendo la tradición seicentista la emparenta en su elogio con la Antigüedad ${ }^{37}$, Viera -más crítico y disconforme con la suya, sólo la aprueba una vez la contempla escenificada para la fiesta ${ }^{38}$.

Por lo que toca a Las Palmas, su dilatada extensión y mostrarse separada en dos grandes barrios - Vegueta y Triana - por el barranco de Guiniguada, podemos identificar dos escenarios. El principal, abarca parte de Vegueta, donde se alojaba la Iglesia, administración y habitaciones de los

El largo lapso fue aprovechado con intensidad. El retrato de Carlos III fue realizado por Juan Rodriguez de la Oliva. El diseño tan perfecto de las jornadas se debió al propio Viera y Clavijo y la penuria económica fue resuelta gracias a la generosidad del regidor perpetuo Roberto de la Hanty y las dádivas del altérez mayor en funciones. Domingo de la Guerra, que lanzó monedas en los actos de proclamación y ofreció bailes en su casa los tres dias de las fiestas. Cfr. la relación de Viera. Sobre el retrato Gallardo PENA, M., art. cit con bibliografía sobre el autor.

"Arquitecturas efímeras, ornatos y máscaras. El lugar y la teatralidad en la fiesta barroca". En El Teatro (Coord. Diez Borque), págs. 41-70. Boner Corre.A. A., "La fiesta barroca como práctica del poder», en Daiwan (Zaragoza) 5-6 (1979), págs. 53-85 y Fiestas, poder y arquitectura. Aproximaciones al barroco español. Madrid, 1990.

"La nobilísima y fidelísima Ciudad, cabeza de esta Isla de Gran Canaria y de las siete de su Provincia, tan venerada de los antiguos, que por su temperamento apacible, fertilidad de su suelo, benigno, hermoso y salutifero cielo, creyeron ser los Campos Eliseos y Centros de las almas bienaventuradas, por que lo cantaron con el nombre de Afortunadas", op. cit., pág. 21. El texto es modelo de su bien cortada pluma.

"La blancura de todas sus paredes, la pintura de sus ventanas, el aseo de sus anchas y largas calles, y las nuevas galas de sus habitadores, daban a la ciudad un ayre de phisonomía noble. que muchos, al golpe de la inopinada perspectiva dudaban si aquella era la Laguna, de cuyo material hermosura se suele tener una idea poco ventajosa", op. cit.. pág. 3 . 
poderosos. Centrábanse alrededor de la plaza de Santa Ana, entre la Catedral y las Casas Consistoriales. Al Norte del Guiniguada Triana, barrio comercial de calles cortadas en ángulo recto, apto para el desfile de cabalgatas o entrada de los que acudían en romería de los pueblos del interior. Triple distinción que señalamos en el plano trazado por Pedro Agustín del Castillo en $1686^{39}$ (Lámina V).

Situada en una planicie, La Laguna carece de un epicentro festivo. Podríamos distinguir tres escenarios: las Casas Consistoriales al Naciente, presidiendo la plaza del Adelantado. Y las dos parroquias con fachadas a plazas más reducidas. Al Poniente la de Nuestra Señora de la Concepción y en el centro Nuestra Señora de los Remedios. Unían los tres núcleos, la calle de la Carrera y la Real ${ }^{40}$ (Lámina VI).

Estos sectores -escenarios urbanos-por lo general lúgubres, abandonados y sucios, en la coyuntura excepcional de la fiesta transformábanse «por obra y arte del disímulo en espacio ficticio y fantástico, virtual escenario festivo, en el que se revela el afán escénico de lo urbano, los ideales profundos y nunca satisfechos de un pueblo y la unión momentánea de todos los individuos" ${ }^{41}$.

\section{Los sentidos de la fiesta}

El aspecto lúdico lo define con acierto Maruri Villanueva al definirlo como "el juego de los sentidos y el sentido del juego" "42. En efecto, los sentidos en la cultura del barroco desempeñan un papel trascendental. No sólo en lo referente a los espectadores, también por lo que toca a los actores y artífices. En las fiestas los cinco sentidos entran en acción, aunque quizás el tacto de forma más marginal. Sentidos que pervivirán a lo largo de la centuria, aunque con alguna matización.

El protagonismo corre a cargo de la luz. Maravall advierte, "con la iluminación, esas artes representan el afán de desplazar el día por la noche,

Descripcion de las Yslas de Canaria, compuesta por D.

Alférez Mayor y regidor perpetuo de la Isla de Canaria.. Año de 1686. Ed. facsimil. L.P.G.C.; C.I., 1994. Por no ser mayor de edad, llevaba por segundo apellido León que permutó a los 25 años por Ruiz de Vergara.

4. Por proximidad cronológica y claridad inserto el plano del marino francés Chevalier d'isle (1779). Reeditado por el Ayuntamiento con motivo del $V$ Centenario de la fundación de la Ciudad. En el mismo puede observarse a la derecha el convento y plaza de San Francisco, donde acampó el Regimiento de Güimar.

4. Montelongo, op. cit., pág. 47

Art. cit., pág. 446 
Fiestas reales en el Setecientos en Canarias. Identidades, evolución y...

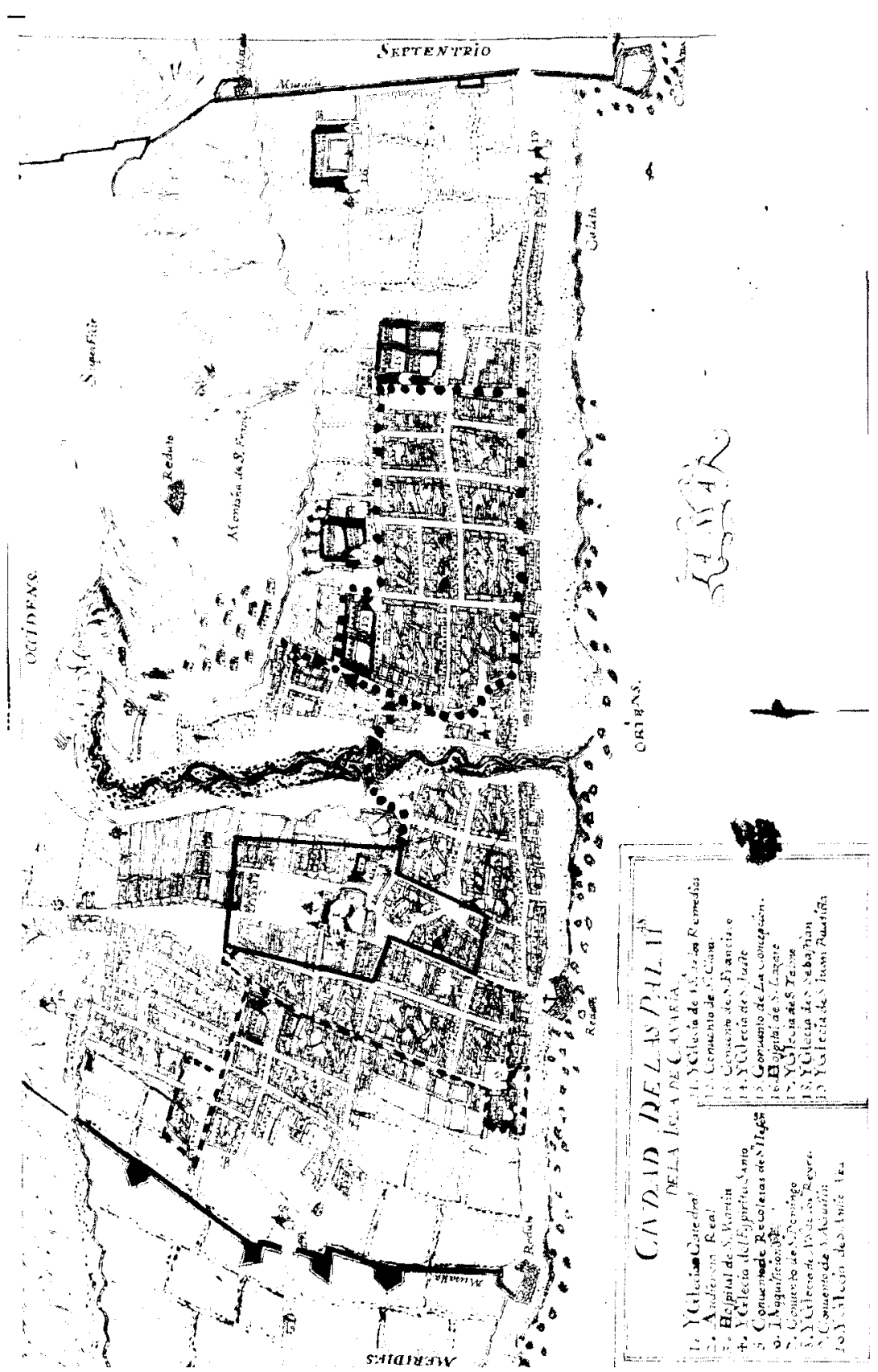

Lámina V. Plano de Las Palmas por Pedro Agustín del Castillo. 1686. 


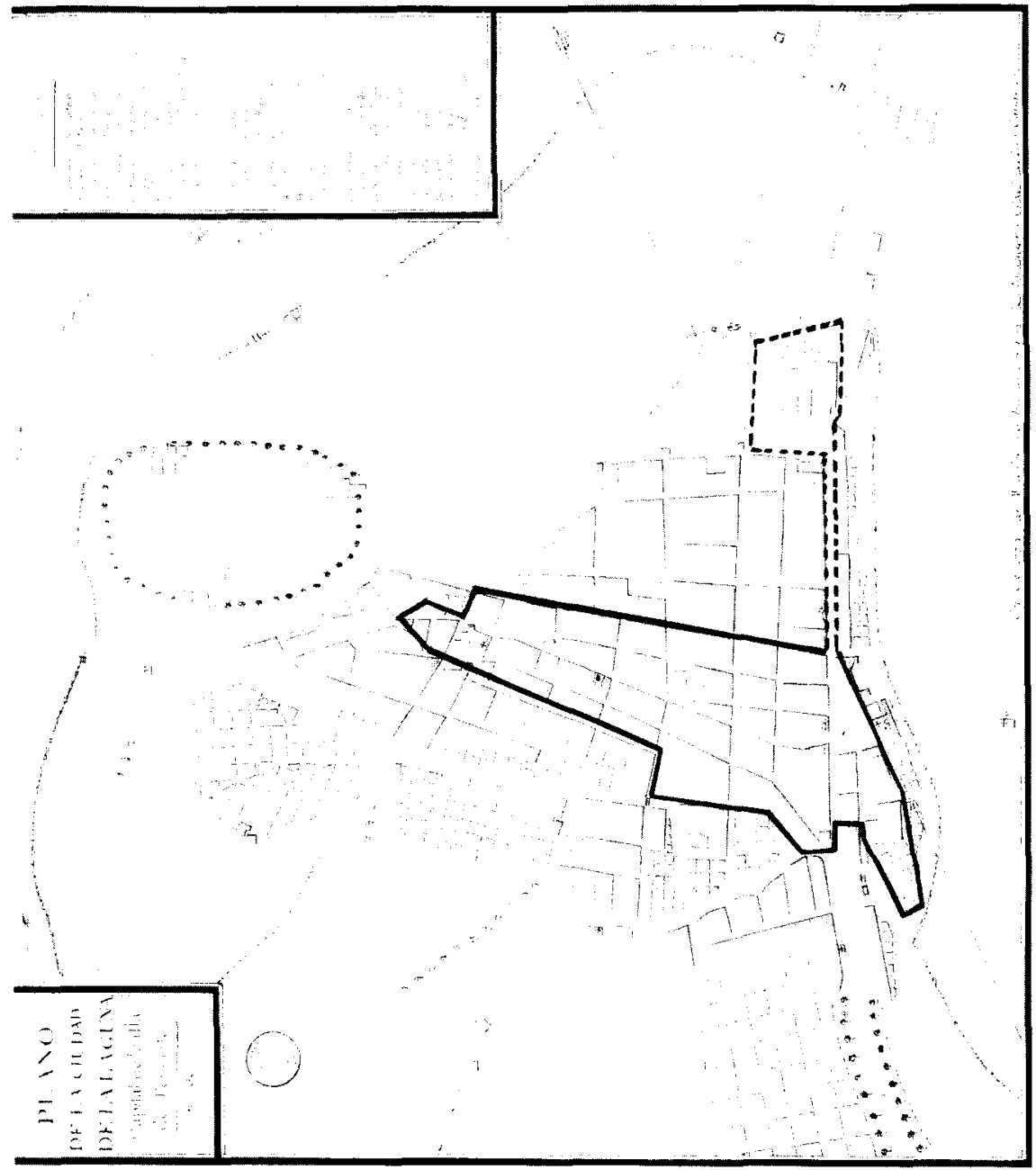

Lámina VI. Plano de La Laguna por Chavalier d'sle, 1779. 
venciendo la oscuridad de ésta por medio de un artificio humano" ${ }^{43}$. Impresiona por tanto a la vista y logra el contraste de claroscuro tan caro a la estética barroca.

Papel que juegan las luminarias en las fachadas, los alardes pirotécnicos, la cera en los oficios sacros, las teas de los acompañantes. En Canarias trasladaban la espectacularidad al medio rural mediante hogueras en las laderas de las montañas ${ }^{44}$. En fin, el viejo culto de temor, aunque indispensable, al fuego. Todo en lenguaje comprensible para el ánimo del espectador.

Al goce de la vista, sumemos el del oído. Órganos y voces en los templos, las espléndidas interpretaciones de la Capilla catedralicia bajo la dirección del famoso Diego Durón de Ortega, dentro o fuera del templo. El maestro compuso piezas y villancicos alusivos al nacimiento del príncipe ${ }^{45}$. Música culta, pero también música y cánticos populares con que se acompañaban los bailes en las mojigangas o en las cabalgatas. Castillo es minucioso y nos dicta los instrumentos más usuales ${ }^{46}$.

$Y$ frente a la música, el atronador ruido de la pirotecnia, las tracas, los cohetes, las descargas de todo género de armas de fuego de los milicianos en evolución: arcabuces, retacos, fusiles y hasta la artillería de campaña, y en ciertos momentos fogueo de los cañones de largo alcance. Si añadimos el repique de las campanas tendremos un conjunto que aturde $y$ acelera la exaltación.

Luz y sonido, pero también el olfato. El incienso de las celebraciones, la pólvora. El placer de los perfumes y afeites en recepciones y bailes, pero también el emanado de los manjares, selectos o populares. Así hemos enlazado con el gusto. En Las Palmas en 1707 no faltó durante

\footnotetext{
43. La Cultura del Barroco. Análisis de una estructura historica. Barcelona, 1983; págs. 447 y 497.

no sólo llenó de luminaria en las tres noches sus casas, sino una alta colina que lo domina y a sus luces pasearon ridiculas y alegres mojigangas" en Guia y en Gáldar "llenaron de hogueras desde el medio hasta la cumbre de las eminentes montañas de la Atalaya y Amagro, dando claridad a la dilatada campiña y a su poblado». CASTILLO, op. cit., $40 r^{0}$ y $v^{\circ}$.

45 La TORRe, Lola de, "La capilla de música de la Catedral de Las Palmas", en Mili aRes TORRES. Historia General de las Islas Canarias. L.P.G.C. Ed. Edirca, tomo IV, 1977, págs. 270- 279. Torre de Trujillo, L. y Siemens Hernández, L., Historia de la Capilla de la Catedral de Las Palmas (ss. $x V \|$ y $x$ VIII). Texto de presentación del disco. Madrid. M.E.C., 1974. TORHF. DE TRUJILLO, L., "La Capilla de Música de la Catedral de Las Palmas y el compositor Diego Durón". En El Museo Canario, XXIX, págs. 85-88 (1963), págs. 39-49. Castillo reproduce la letra de alguna de sus composiciones entonadas desde las ventanas del palacio episcopal y el silencio con que fueron escuchadas por el pueblo.

${ }_{46}$ Tambores, tamborines, clarines, falutas, chirimias, laus, violines, vihuelas, arpas, liras, sacabuches, cornetas, panderos, campanillas, caracolas, carracas, etc. etc
} 
tres días varias fuentes públicas y en casas de principales para que saciaran la sed los amigos de Baco ${ }^{47}$.

Aunque en menor medida no falta alguna referencia al tacto, que también entra en este juego sensitivo: danzas y bailes, ricas telas, tapices y damascos adornando fachadas e interiores de edificios públicos y privados. El lector está en su derecho en imaginar otras variedades tactiles, silenciadas prudentemente por los autores de las relaciones.

Aún podríamos añadir el teatro, pero sobre este género tan popular en Canarias volveremos.

En conclusión: todo un lenguaje que prueba cómo en Canarias también se disfrutaba del cjuego de los sentidos y el sentido del juego" enunciado por Maruri.

\section{LOS ACTORES}

\section{Sacralización}

Es lógico que un pueblo de fe tan arraigada expresara en estas festividades acciones de gracias y ruegos para que no faltara en el futuro la protección divina al recién nacido o recién coronado como rey, de la que en alguna medida disfrutarían los súbditos. Con ello volvemos a la concepción del servicio obligatorio a ambas majestades. En sincronía, la Iglesia para sus fines y concepción tratará de utilizar la sacralización del tiempo festivo. Así lo asevera Álvarez Santaló: «Exceso sensorial con fines propagandísticos para activar, conmover y mover a los fieles a aceptar el discurso religioso - una cosmovisión en útima instancia-importante para la Iglesia» ${ }^{48}$.

Tanto en Las Palmas como en La Laguna no faltaron estas ceremonias plenas de magnificencia. Te Deum en la primera costeada por el Cabildo en la Catedral, y San Agustín, ante el milagroso Cristo patrono de la Ciudad. Tampoco faltaron los aportados por la Audiencia y el Santo Oficio en Santo Domingo. Un octavario en la basílica por el Cabildo y un novenario

\footnotetext{
Aunque Castillo cita alguno de los manjares selectos, no alude a los populares, que fueron ricos y variados y se han conservado hasta el día de hoy. En Los "Quadernos" del comerciante de la calle de la Peregrina Don Antonio Betancourt, con amplia introducción del que suscribe, no sólo ha dejado alguna receta culinaria, sino de botica. L.P.G.C.: C.I., 1996.

4e "La religiosidad barroca: la violencia devastadora del modelo ideológico". En VII Encuentro de Historia y Arqueologia. Gremios. Hermandades y Cofradias. San Fernando (Cádiz), 1991; pág. 77
} 
de la Audiencia en el convento de Santo Domingo. El gremio de los escribanos públicos en Santa Clara y el de los libertos y esclavos en los dominicos, etc. Ceremonias rodeadas del mayor boato, con los mejores oradores sagrados y música y coro, cortando la palma, como es lógico, la Capilla catedralicia.

No faltaron actos sacros en La Laguna durante los tres días de proclamación de Carlos III, que se hizo desde las fachadas de la Concepción y Los Remedios. Nos llevaría muy lejos relatar la riqueza alegórica desplegada por Viera y Clavijo ${ }^{49}$ para honrar la esfinge del nuevo monarca, las décimas y glosas latinas, o la enorme pintura con la llegada a Barcelona de la escuadra que conducía al Soberano desde Nápoles, a los que ya hemos hecho alguna mención. Únicamente quisiera destacar la plata acumulada en frontales, candelabros, varales, etc., auténtico «Potosí» en imagen de Viera, ante tal cúmulo de rica orfebrería, objeto de estudio del recién fallecido don Jesús Hernández Perera con su habitual maestría ${ }^{50}$; así como el diálogo entre la imagen de la Virgen y la representación de Carlos III ${ }^{51}$.

\section{Cohesión social y estamentos}

Cohesión sí, pero con matices estamentales. El acuerdo entre autores es unánime, así como el gradiente cohesivo a lo largo de la centuria. Si en los inicios del Setecientos el pueblo es un partícipe solidario con iniciativas, a fines del mismo su papel se queda reducido al de mero comparsa que representa lo que la élite le encomienda en pro de la lucidez del espectáculo o a mero contemplador. Se cumple el axioma "todo para el pueblo, pero sin el pueblo».

En Canarias encontramos otros aspectos de diversidad. Como el sector primario pesa tanto en la economía insular, en las fiestas se da paso a la escenificación agraria con la participación del campesinado y sus labores, e incluso mediante alegorías mitológicas. Claro contraste con una ciudad periférica, Santander, donde el juego se reduce a lo urbano ${ }^{52}$.

\footnotetext{
Todo ello recreado minuciosamente por el propio VIERA, a lo largo de su op. cit. Orfebreria de Canarias. Madrid, C.S.I.C.. 1981.

«Reciproca protección / de ti espera la fée mia: / Tu para mi Monarchía / Yo para tu Concepción./ Tu me das la posesión...» en las décimas.

bi: MaruRI Villanueva, $\mathrm{R}$, el art cit. es un buen banco de prueba de las singularidades insulares; págs. 460-61, particularmente.
} 
De otra, se escenifican temas enraizados con su peculiaridad atlántica: representación de combates navales ${ }^{53}$, diálogo entre la nave y el casti$110{ }^{54}$, la temática indiana ${ }^{55}$, sin que falte el mito de las Afortunadas, o el Jardín de las Hespérides ${ }^{56}$. Temas sobre los que volveremos.

Las matizaciones estamentales ya las hemos contemplado en el apartado dedicado a la sacralización de las fiestas. Ahora expondremos la participación en la élite de poder insular (Cabildo y poderosos) y las propiamente populares.

\section{Las instituciones}

Aunque la Audiencia participe con ceremoniales eclesiásticos, los programas son costeados y protagonizados por los regidores de los municipios-islas, o sea los Cabildos. Hay diferencias entre las dos islas, pues en Tenerife reside el Capitán, luego Comandante General, y en ambas ocasiones el Obispo se encontraba en dicha Isla. Sin embargo, ambos Cabildos seculares invitan a todas las autoridades y personas cualificadas, sin olvidar el clero. Cuando predomina el barroquismo, los pueblos y gremios costean sus participaciones, mientras bajo la llustración es el Cabildo o sus regidores quienes costean los espectáculos de toda índole. Podríamos añadir a la diferente coyuntura económica y a la nueva sensibilidad ilustrada (intimismo, reducción de espectáculos, rendimiento en el trabajo, reducción del ocio y días festivos, etc.), otro factor de no menos peso, que explican la extensión festiva para celebrar el nacimiento del príncipe. El mesianismo, la adhesión a la nueva dinastía, las esperanzas en el activo Felipe $V$, que supondría el final de las levas y los frecuentes y costosos donativos, frente a los riesgos de un programa centralista.

Los festejos más espectaculares fueron financiados el 22 de septiembre por el Cabilo; el 24 y fines de octubre por el Cabildo catedralicio como apertura y cierre del octavario y el 2 y 11 de éste, por la Audiencia para enmarcar el novenario celebrado en Santo Domingo ${ }^{57}$.

3 CAstillo, op. cit., $27 v^{\circ}$.

54 Todavía se mantiene viva esta tradición durante las fiestas lustrales en Santa Cruz de La Palma. Veáse Descripcion Verdadera de los Solemnes Cultos... que la... Ciudad de Santa Cruz de La Palma consagró a Maria Santísimia de las Nieves... 1765. Ed. de A. ABoo y P. REY. S/C de La Palma. Escuela Municipal de Teatro, 1989.

55 El tema del cohico presentado por los vecinos de Arucas. CASTILLO, op. cit., pág. 26.

56 VIERA Y CLAVIJO, págs. 28-31 y el programa de mano. O la rendición de los Guanches a Alonso de Lugo, tema central del carro en la coronación de Carlos IV. GALLARDo PENA, art. cit.

57 Se echa en falta la colaboración del Santo Oficio, todo lo redujo a un Te Deum en los dominicos, sabido es que su financiación nunca fue desahogada. 
Tienen el mismo escenario los cinco: la Plaza Mayor o de Santa Ana. La erección de desmesuradas y sólidas arquitecturas efímeras, los ricos adornos de tapices, banderas y gallardetes a lo largo de las fachadas que marcan el paralelogramo, las luminarias, los árboles pirotécnicos, etc., etc.

Así, por ejemplo, en el costeado por el Cabildo, un Castillo con todos sus aditamentos, almenas, saeteras, barbacanes, de enormes proporciones, y en las esquinas cuatro erguidos árboles pirotécnicos ${ }^{58}$.

El 24, iluminarias a las que añadieron los canónigos doce árboles pirotécnicos, más todo el juego capaz de las anteriores instalaciones ${ }^{59}$. Pero el máximo esplendor se alcanzó en la clausura del octavario. Se levó una torre de 93 pies de altura, en tres plantas con sus balaustradas imitando mármol. En todas ellas se hicieron artificios pirotécnicos, estruendo al que se sumaba el repique de las cinco campanas que la coronaban. Momento culminante, cuando es restablecido el silencio, se oyó desde los balcones del palacio episcopal la orquesta y coro de la capilla catedralicia bajo la batuta del maestro Durón ${ }^{60}$.

No nos detenemos en las dos representaciones que corrieron a costa de la Audiencia, a fin de evitar reiteraciones, con algún matiz. Pero merece llamar la atención sobre el lujo de espectaculares escenificaciones con la serenidad de las coronaciones carolinas.

\section{Los poderosos ${ }^{61}$}

Como venimos repitiendo, aunque las fiestas fomenten la cohesión social, los estamentos las aprovechan para mostrar su poderío y modelo al

58 La torre del homenaje de 25 pies geométricos, coronaba la fortaleza de 20 pies. Desde la misma un palenque que conducía hasta las casas municipales, rematada por figura femenina de dos caras, armada de espada y rodela. Todas las fachadas adornadas con banderolas en "las que las armas de esta leal Ciudad decia bajo quien militaban amantes y obedientes". CASTILLO, op. cit., pág. 26 vo.

59 “... quedaron dibujadas en el aire vanas y ardientes formas, con tal estrépito la multiplicidad de tronadoras bombas, redines y ruedas, que en mucho tiempo que duró esta confusión no se pudo diferenciar nada de lo que entre tanta luz había". CASTILLO, op. cit., págs. $26 v^{\circ}$ y 27 rº.

$60 \quad$ «... a que se dio principio con el luminoso farol que se formó en las torres y cornisas del templo y columnas, los muchos faroles que se situaron en la plaza..."; "... pegandose por el suelo ardientes montantes y por largas cuerdas veloces rayos... se vio el mayor lucimiento en los árboles y torres por ser remate en rizados penachos de luces». La torre de artificio estaba coronada por una figura femenina, que sostenia en un brazo una espada y en la otra una bandera. Castillo nos ha conservado la letra de una de las composiciones. Destacan los versos: "Volcanes reviente en esa que eleva / pirámides hermosas, duice Mungibelo / que en luces y rayos espira y es Etna", rematada con un "viva siempre y triunte el Gran Felipe / nuestro amado Luis y hermosa Reina". CASTILLO, op. cit., pág. 37 ro y vº.

61 He preferido esta acepción de Domínguez Ortiz, pues en Gran Canaria el primer título nobiliario lo alcanzó Fernando Bruno del Castillo, hijo de Pedro Agustín en 1777. En Tenerife no 
pueblo, pues por estar basada en el privilegio. Con palabras de Maruri: como "modelo y espejo", aprovechan la ocasión para mostrar "Sus destrezas, sus galas, sus danzas y sus ademanes", espejo en donde el resto de la sociedad pudiera mirarse $" 62$.

También en las Islas el primer signo de esta diferenciación la encontramos en las Casas consistoriales. Durante las fiestas se transforman en hogar donde se acojen a autoridades, visitantes de importancia, alto clero y la élite local, reflejos del poder central ${ }^{63}$. Es más, como las relaciones tienen como objetivo satisfacer la curiosidad de los cortesanos, los autores no omiten un solo nombre de este grupo, en cuyas manos recae el poder local. Es curiosa la diferencia entre Castillo y Viera.

Aquel, como uno de los más prepotentes es ávaro en las citas. Viera, un clérigo con porvenir, pero un recién llegado, no se deja uno solo en el tintero. De todas formas es un índice de la impostancia del status de los relatores.

No faltan los actos propios y exclusivos donde los poderosos se lucen como prepotentes. Los regimientos estrenan en Tenerife uniforme, los caballeros lucen sus mejores galas en los desfiles, con servidores luciendo llamativas libreas, las monturas ricamente enjaezadas ${ }^{64}$. Justas de cañas por parejas, lidian toros a caballo ${ }^{65}$. En otras palabras, se envanecen sosteniendo un lenguaje cortesano, aspirando a vincularse en alguna medida a la "mística de la realeza". Aprovechan, así, los actos festivos "para autoexaltarse de cara a sus propias comunidades" y al tiempo tratan de hacerse notar ante el monarca y su entorno ${ }^{66}$.

No fue menor la exhibición elitista en La Laguna, aunque faltaran correr toros o jugar cañas. La diferencia estuvo sobre todo en el papel jugado por los tres regimientos de Güimar, La Laguna y Tacoronte con toda su oficialidad y sus acampadas, desfiles, evoluciones y descargas con recién

\footnotetext{
escasearon los titulados, pero no fueron, salvo excepción, señores de vasallos, ni gozaron de todos los privilegios que en la Península.

"... de ellos se espera determinados comportamientos y estaban obligados a mostrarlos a los demás». Art. cit., págs. 460-61

63 La descripción de MONTELONGO ROBLEDO, op. cit., pág. 50, es altamente significativa sobre lo que representaron, como alhajaban y disfrutaban de los refrescos.

os Castillo, op. cit. pág. 23 vo.

65 a... tomaron [los caballeros] varas para citar a los toros, que subiendo al campo de lidia, cuando creyeron correrlos burlandose de la común mansedumbre que tienen los de este pais, se hallaron bastante engañados, viéndose en muchos lances, legado al tenor el regocijo, saliendo he. ridos tres caballos, y del mayor peligro de sus jinetes", op. cit., pág. 36 .

66 Maruri Vil lanueVa, R., art. cit., págs. 56 y 60.
} 
estrenados uniformes ${ }^{67}$, frente al desfile en Las Palmas de los 60 infantes pagados por el Rey para defensa de castillos y fortalezas ${ }^{68}$.

\section{El pueblo}

"La cohesión social es lo que refleja una ciudad en fiestas, en la que los diferentes grupos y asociaciones urbanas participan en la preparación y desenvolvimientos de las funciones". Como asevera la doctora Montelongo ${ }^{69}$.

En Canarias, quisiera añadir, la acción popular no se reduce sólo a "grupos y asociaciones urbanas". Aquí se adhieren a la fiesta las comunidades rurales, participando en las de la capital o celebrándolas en sus respectivos pueblos. Aunque esta presencia vaya atenuándose al discurrir la centuria y acabe reduciéndose a meros comparsas de programas ideados por intelectuales.

Desde otro ángulo, lejos de lo que ocurre en Santander y otras ciudades peninsulares, en Canarias gozan de un claro protagonismo los temas agrarios y localista tanto a nivel popular como en las complejas alegorías de las cabalgatas. Antecedentes manifiestos hasta el presente, como los temas carnavaleros.

Finalmente, aun en los motivos de inspiración más sublimes, no faltan ciertas notas humorísticas. Pero estas anotaciones no merman por supuesto como eje la relación entre fiesta y poder ${ }^{70}$.

La complejidad de las manifestaciones populares quedará más clara si las agruparamos en tres variedades: mojigangas, participación rural y urbana o gremial.

\section{Las mojigangas}

Los ejemplares más claros sobre la participación humoristica fueron los que recorrieron la ciudad de Las Palmas las noches del 16 y 17 de

\section{VIERA y Clavijo, op. cit., págs. 11-12 y 16-17}

68 Aunque abonaran el montaje de un palenque y dos árboles "de festivas invenciones de fuego", sus esfuerzos quedaron deslucido porque "algunos en los vestidos por la cortedad del suelo" no alcanzaran la necesaria marcialidad. CASTILLO, op. cit., pág. 37.

69 Op. cit., pág. 47.

: Op. cit., pág. 48 y “los mecanismos de escenificación” en MARURI, art. cit., pág. 461. 
septiembre y 23 de octubre. Atinadamente ha sido observado el antecedente de estos desfiles con "las fiestas de locos" ${ }^{71}$.

Su espontaneidad no escapa a Castillo. Afirma «las dispuso el efecto común", reduciéndolas a "ridículas figuras vestidas de extraños disfraces montados en camellos y jumentos" 72 . O la del 18 réplica del lujoso desfile de autoridades y caballeros, en la que mozos de la ciudad y pueblos realizaron otra "entretenida mojiganga de muchas figuras vestidas con varios y ridículos disfraces, todos en malos caballos y jumentos" ${ }^{73}$.

Carácter muy diferente tuvo la del 28 . De carácter mitológico, iba presidida por un carromato en el que una representación del dios Baco, figura inmoral rodeado de otras seis deidades significativas del Olimpo. Tiraban del carro animales disfrazados de elefantes, jabalíes y otras fieras y escoltado por otros muchos mozos disfrazados de todo género de animales. Reflejo de amor hacia la Naturaleza. Representaron un muy divertido y alegre sainete en el que los dioses y brutos eran invitados a celebrar el nacimiento del Príncipe ${ }^{74}$. Su mayor mérito fue la de ser ideada por el vecindario de Teror.

\section{El mundo rural}

Como ya subrayamos, peculiaridad insular, en un doble escenario, en la capital o en su localidad, por lo menos hasta la segunda mitad del siglo XVIII.

Por lo que toca a los pueblos más poblados, tanto de la banda oriental como septentrional, Castillo destaca los de Telde y Agüimes en aquella y los de Guía, Gáldar y Agaete en la segunda. El esquema es semejante: luminarias, carrera de sortijas, mojigangas, toros y en casi todos representaciones de comedias. Éstas oscilaron entre cuatro y una, que no faltó en la entonces más pobre, Agaete. La comedia, acompañada de entremeses y loas alusivas a la convocatoria. Ya hemos destacado la gran hoguera en la cumbre de la montaña de Guía, las extendidas en Gáldar en las laderas de las montañas de la Atalaya y Amagro. Como en el resto de la nación tienen fama las hogueras de San Juan, que tanto impresionaron al barón de Humboldt ${ }^{75}$.

\footnotetext{
Maruai Villanueva, R., art. cit., pág. 450

CASTillo, op. cit., págs. 23 y 37.

Op. cit. Locs. cits.

Como nota humoristica, la cabalgata iba presidida por la tarasca del Corpus y rematada por un banquete en el que se cruzaban brindis. Op. cit., pág. 37

75 Op. cit., pág. $25 r^{\circ}$ y $v^{\circ}$.
} 
Otras localidades, por el contrario, decidieron mostrar su ingenio participando en la alegría de la capital ¿orgullo? ¿méritos? Interesan por su variedad. Sorpresiva fue la invasión el 19 de septiembre al circular por las calles más de docientos pastores y sus rebaños, "publicando con sus rústicas voces su alegría, al son del tamborino, flautas y otros instrumentos agrestes».

La tarde del 23 hicieron su presencia los vecinos de la Vega, vestidos de "zamarros" 76 . Recorrieron las calles con bailes acompasados a las faenas agrarias: siega, siembra, etc., incluso un arado enyugado, que simulaba realizar su función. Ante las autoridades, el capitán de la compañía de milicias del lugar, ya octogenario, echó pie a tierra y con voz potente hizo una larga proclama de fidelidad al recién nacido ${ }^{77}$.

Y en ese día, ya anochecido, acudieron los de Arucas. Una iluminada cabalgata, iba presidida por un carro ricamente adornado. Sobre él un "cohico o casa de indios", de la que salía una india y su marido y "diez indiecitos desnudos y con un jarretín rojo". Galanes y muchachas las precedían y escoltaban con danzas de cintas y pañuelos, que llamaron poderosamente la atención ${ }^{78}$.

Como quiera que la defensa de las islas estuviera encomendada exclusivamente a las milicias provinciales, es de advertir que el gran número de milicianos conservaban en casa sus armas ${ }^{79}$. Por tanto en cualquier cabalgata rural o urbana solia ir precedida y seguida de escolta que disparaban sus fusiles, arcabuces o mosquetes. De nuevo los sentidos: vista, oído, olfato...

Quizás la más hermosa fuera la cabalgata que Viera bautiza con el nombre de Carro de los labradores en La Laguna, en los de Carlos III. Organizada por el gremio de labradores caracteriza la esencia agraria de las Islas. Como tema central, "El triunfo de Ceres y Tripademos». Encabezaba la marcha un cuerpo de dos docenas de labradoras y labradores que bailaban cen torno a Misme, vieja ridícula, que iba moliendo gofio en un pequeño molino de gofio" ${ }^{80}$. Seguían al carro grupos que imitaban todas las labores desde la siembra a la trilla. En el carro central la diosa

\footnotetext{
Zamarrón. "Delantal con que se protegían los segadores". LORENZO, A.; MORERA, M., y Ortega, G.. Diccionario de canarismos. La Laguna. F. Lemus, 1994, pág. 352

CAStillo, op. cit., págs. $25 v^{\circ}$ y $26 \mathrm{r}^{\circ}$.

Op. cit., pág. $26 r^{\circ}$ y $v^{\circ}$.

Rumeu de Armas, A., Canarias y el Atlántico. Piraterias y ataques navales. Canarias: Gobierno de Canarias, 1991.- $2^{\text {a }}$ ed. 3 tomos en 5 vols. Caps. $X X, X X I$ y XXXV

Bo VIERA y ClAvijo, op. cit., pág. 13. El gofio era alimento sustancial en las Islas. Maiz o trigo, tostado y molido. Todavía hoy se consume y es esencial en platos de la cocina canaria.
} 
Ceres, protectora de la agricultura rodeada de figuras mitológicas, seguido de otro ricamente adornado en el que Ceres y su hija Proserpina ofrendan productos a un retrato del monarca. Cerraba el cortejo la "Brigada de Baco, dios del vino, por tener este tanta afinidad con el pan, y ser este ramo de la agricultura [el del vino] fruto tan principal de Thenerife" ${ }^{81}$.

\section{Participación urbana}

En Canarias no podían faltar las alusiones al vino no sólo por la significación del mismo en la economía insular, sino por la inveterada costumbre de su consumo en las diferentes capas sociales. En Las Palmas durante "tres días y noches se aumentaron en los amantes de Baco sus glorias con las diferentes fuentes que estuvieron perennes de su licor en las calles y casas de algunos caballeros" ${ }^{82}$.

Por lo que toca a la participación popular de los ciudadanos, los festejos se realizaban por obra de gremios y sus cofradías o hermandades. Se distiguian una triple diferenciación: funciones eclesiáticas, desfiles o cabalgatas y representaciones teatrales, aunque en estas alternasen con las representaciones del Cabildo.

\section{Los gremios}

A las primeras ya hemos hecho alusión. Por el número de afiliados podían reducirse a sólo una acción de gracias, o alternarla con manifestaciones públicas.

Entre las acciones de gracias las solemnidades costeadas por los mercaderes en la iglesia de la Compañía, los escribanos públicos en la del monasterio de Santa Clara o la de la Hermandad del Santísimo Sacramento en la Catedral. En este caso tuvo lugar la tradicional representación de una nube que abierta en lo alto de las bóvedas, producía lluvia de pétalos de flores, dulces, confituras y «cedulillas con festivos motes» ${ }^{83}$.

\footnotetext{
B. Op. cit., págs. 13-16. "No puede imaginarse representación mas popular para aclamar y celebrar a su Rey Carlos III, ofreciendo sus corazones, frutos y sudores que hacen fondo considerable de las felices Monarchias", nos dice Viera (16). Baco a caballo seguido de las Bacantes. El autor nos explicita el significado alegórico de cada uno de los personajes mitológicos. Labor que cumplimenta Gallardo Peña, art. cit., págs. 277-280.

E2 CAstillo, op. cit. pág. $29 \mathrm{v}^{\circ}$

83 Loc. cit. Podriamos añadir la de la infantería real el 15 de octubre, festividad de Santa Teresa en el convento de la Veracruz, o sea en los agustinos.
} 
En el segundo grupo tenemos las manifestaciones públicas tanto en Las Palmas como en La Laguna. Destacan entre aquéllas el desfile de la gente de mar con su capitán al frente, que alegran al público entre las descargas de la fusilería con "danzas de espadas al son de chapas y pandero, tambor y clarín" ${ }^{84}$, la de los "Estudiantes de Gramática y artistas", por la belleza con que "aplaudieron la grata dicha en una bien dispuesta relación" ante las casas municipales ${ }^{85}$.

Pero quizás la más curiosa intervención fue la de la Hermandad de Libertos y Esclavos, por la variedad de la misma ${ }^{86}$. Hubieron de solicitar licencias y pedir generosas ayudas. Pero el esfuerzo no resultó baldío: función religiosa espléndida en Santo Domingo, donde radicaba; un muy animado desfile con trovas al acontecimiento y tres representaciones de comedias en las que no faltaron «alegres músicas, divertidos sainetes y burlescos entremeses, finalizando en la noche con una alegre pandorga" ${ }^{87}$.

Mención aparte merece por lo que a Canarias se refiere el significativo lenguaje que encierran las cabalgatas de los gremios agrupados aquí bajo los Cabildos insulares, que son los que autorizan el grado de oficiales. Tanto es así, que, como la agrupación de Las Palmas no quedara complacida con su exhibición, montaron otra segunda, en la que se nos aparece la contribución de Pedro Agustín del Castillo. Y no digamos de la espléndida representación de la gloria de Tenerife como Jardín de las Hespérides, ideada y realizada por Viera y Clavijo, quien incluso redacta un programa de mano explicativo del significado de la cabalgata.

Por lo que toca a 1707, el 7 de octubre desfilan los gremios de oficiales, con sus alcaldes al frente, luciendo adornadas libreas. El "carro central» lo culmina "una ninfa que representa a esta Isla Afortunada y al Amor con que siempre ha estado rendida a sus Monarcas" ${ }^{88}$. Llegado ante las autoridades entablan Isla y Amor una loa a los Reyes y el príncipe. El error estuvo en no admitir la colaboración de los aprendices, quienes al día siguiente hicieron presencia con una lucida cabalgata, con carro muy en-

$\varepsilon_{4}$ Op. cit., pág. $39 r^{\circ}$.

85 LOC. cit.

de Lobo Cabrera, M.; Lopez Caneda, R. y Torres Santana, E., La "otra" población expósitos, ilegítimos y esclavos (Las Palmas de Gran Canaria siglo xvm). Universidad de Las Palmas de Gran Canaria. L.P.G.C., 1993; págs. 113-142.

CASTILlo, op. cit. págs. $38 \mathrm{r}^{0}$ y $\mathrm{v}^{\circ}$. Consistía la pandorga en un juego. Un estaferno con rodela y unas bolas o sacos con arena, al ser herida aquélla por la lanza de un jinete, giraba y lo golpeaba en la esplada, si no pasaba con la necesaria rapidez.

38 Op. cit. pág. 36 ro. Rodeaban al carro doce turcos «ostentosamente vestidos y danzaban delante doce etiopes vestidos de rojo" 
galanado con los retratos de Felipe $\vee$ y María Luisa de Saboya bajo dosel y a sus pies una cuna ricamente aderezada ${ }^{89}$.

La insatisfacción hizo que los oficiales cerraran la larga teoría de manifestaciones festivas, tratando de superar lo lucido de los espectáculos de «libertos y esclavos» o la de Arucas, con nueva cabalgata. El motivo, un carro con el Sol rodeado de los planetas y los signos del zodiaco portados en briosos corceles, en medio de una selva de disfrazados árboles y arbustos ${ }^{90}$. Abría el cortejo una "victoriosa palma". Conjunto de signos todos "favorables a nuestro Príncipe». Quedaron así satisfechos.

Aunque en las fiestas barrocas no escaseaban las alusiones mitológicas, ensalzando alegoricamente la grandeza del poder, su valor significativo va ganando grados, que culminan en la llustración. Es el caso en Canarias de la proclamación de Carlos III, obra de Viera, quien se inspira en la obra de Cristóbal Pérez del Cristo ${ }^{91}$.

Fue el desfile más espléndido de cuantos se celebraron en Canarias. Como una detallada descripción nos llevaría demasiado lejos, no me detengo en la variedad y acompañamiento de las ninfas, los guanches de ambos sexos que vestidos de pieles bailaban el canario. Danza hoy desaparecida, pero que tuvo gran aceptación en las cortes europeas de los siglos XVI y XVII. Pero el punto álgido se situaba en la representación sobre un carromato del Jardín de las Hespérides, adornado con manzanos. Al respaldo una representación del Teide y a sus faldas el retrato de Carlos III a quien Hércules después de haber dado muerte al Dragón, le ofrece las manzanas de oro. Leyenda mitológica que de antiguo venía situando el escenario en el Valle de La Orotava, que sirve a Viera y Clavijo para significar la ofrenda de la Isla a nuevo Soberano ${ }^{92}$.

\section{El teatro}

Pero nada tan trascendente en el tema que tratamos como las representaciones teatrales. En efecto, como nos dice Díaz Borque: «en la más

\footnotetext{
Loc. cit. Tampoco faltaron una treintena de arcabuceros.

Loc. cit.
}

Excelencias y Antigüedades de las Islas Canarias. Xerez de la Frontera. Juan Antonio Tarazona, 1679. Hay reproducción facsimilar, precedida de estudio crítico por M. Hernandez GonzALEZ. Gobierno de Canarias, 1996. Cfr. el cap., "Hespérides y Gorgonas".

92 "... nuestra Isla de Thenerife, que conquistada por el Hércules Español Don Alonso Fernández de Lugo, ahora nuevamente ofrece su amor, su vasallaje, sus frutos y caudales a los pies de su mejor Rey Euristeo DON CARLOS III, muerto el Dragón de la infidelidad y de la envidia”. 
pura fiesta barroca celebrativa, el teatro de forma decisiva (por su función difusora propagandista aleccionadora) con la colaboración de las demás, que no puede ser olvidada, si queremos entender el mundo barroco" ${ }^{93}$.

En Canarias si el pueblo acogía con interés y alegría las cabalgatas y desfiles, en especial los bailes que ejecutaban durante los mismos, como he tenido ocasión de señalar, pienso que dentro del género -entendido en el sentido más lato- cabría integrar las marciales evoluciones de milicianos, subrayadas por sus descargas de las armas de fuego. En ambas modalidades cabría interpretarlas como ballets evolucionando en la vía pública.

Sin embargo, fue el teatro el espectáculo tradicionalmente más apreciado desde el siglo XVI. Recordemos el éxito con que fueron acogidas las piezas de Cairasco de Figueroa ${ }^{94}$, representadas en la plaza de los Álamos, detrás de la Catedral.

En contraste con las de 1760 y 1789 , en que tales representaciones brillaron por su ausencia, en 1707 no faltó el género dramático en abundancia. Tanto motivadas por el pueblo como por el Cabildo. Contabilizamos hasta quince en el texto de Castillo a partes iguales entre la capital y los pueblos ${ }^{95}$. Añadamos los sainetes, entremeses, loas y letras con que iban acompañadas en los inicios e intermedios de las comedias.

Pero el género rebasa los estrictos límites del teatro, si rememoramos autos sacramentales, las loas y coloquios sostenidos ante las autoridades por los personajes alegóricos, o los mantenidos entre atacantes y defensores de las efímeras fortalezas, a imitación de los sostenidos entre el castillo y la nave en las Fiestas Lustrales en honor de la Virgen de las Nieves que afortunadamente hasta hoy se conservan.

Si bien las representaciones teatrales no figuran entre los actos oficiales de las proclamaciones de Carlos III y su hijo Carlo IV, era tal el arraigo de las mismas que no faltan en las fiestas patronales de los centros urbanos rurales, como aseveran tantos autores ${ }^{96}$.

\footnotetext{
Explica el propio Viera en su Jardin de las Hespérides, pág. 3. Programa que refleja el espíritu didáctico del autor como advierte ROMEU PALAZUELOS, op. cit., pág. 24

93 Diez BORQUE, J. M., Una fiesta sacramental barroca. Madrid. 1993; págs. 76 y 85.

94 CaIRAsCo de FIGUeROA, B., Obras inéditas. Teatro. Introducción y notas por AlEJANDro CiORANESCU. S.C.T., Goya Ed., 1977, 2 vols

95 Cuatro el Cabildo y tres la Hermandad de Libertos y esclavos frente a los cuatro en Guía, tres en Gáldar y una en Agaete.

98 Guerra, Juan Primo de la, Diario: 1808-1810, ed. de Rosa Olivera, L. de la. S/C de Tenerife. Aula de Cultura, 1976. 2 tomos. Guerara y Peña, L. A., Memorias. L.P.G.C., El Museo Canario, 1951-1954. 4 tomos. MARTINEZ DE LA FUENTE, F., Usos, costumbres y fiestas en Gran Canaria en el
} 
En honor del nacimiento del efímero Luis I el Cabildo «dio orden se hiciese en la plaza de los Álamos un teatro ... que se ejecutó con el mayor primor» ${ }^{97}$.

Como cronista Pedro Agustín del Castillo confiesa: "Siendo estos festejos cómicos en estas Islas destinadas para las mayores celebridades y, porque en ellas no hay compañías de farsa, se ofrecieron celosos los escribanos públicos y otros mozos de ingenio, que fueron en las tablas desempeño del cuidado y admiración a oyentes" ${ }^{98}$.

Es lástima que no se nos hayan conservado los textos de las comedias, aunque al menos, de las encargadas por el Cabildo, Castillo nos ha conservado los títulos. Lo que sí incluye el eximio historiador en su Relación son los textos de las loas, letras y sainetes con que se entretenía al público como salutación o durante los entreactos. Lo cual nos induce a sospechar como hipótesis que el cronista fuera autor de las mismas, 10 que explicaría que conservase los textos ${ }^{99}$. Así ocurrió con Viera, que en su Autobiografía hace constar que las composiciones con que fue adornada la Concepción, tanto en latín como en castellano, fueron producto de su cacumen ${ }^{100}$.

Castillo, por lo que toca a las representadas por libertos y esclavos ${ }^{101}$, se reduce a elogiar en el buen hacer, asi como nos refiere que el éxito de las cabildicias obligaron a repetirlas. De las puestas en escena por los pueblos de la banda de barlovento, se limita apresuradamente a comunicarnos el número de las puestas en escena de cada uno.

\section{CONCLUSIONES}

Estimo que éstas podemos reducirlas a tan breves como coincidentes con las expuestas como posibles hipótesis introductorias al presente trabajo. O sea, las siguientes:

\footnotetext{
siglo xVili. Introducción y notas de Hernandez Gonzalez. L.P.G.C..- R.S.E.AA. del País de Las Palmas de Gran Canaria (en prensa) y Brito GonZALEZ, O., "Las fiestas en Canarias en la época del Barroco", en Algunos estudios sobre el tránsito del Antiguo Régimen en Canarias.- Islas Canarias. Gráfica Tenerife, 1983.

97 CASTILLO, op. cit., 27 ro . No fallaron a la invitación los miembros de la Audiencia, Inquisición y Cabildo eclesiástico que gozaron de lugar preferente.

${ }_{98}$ Op. cit., pág. $38 \vee^{\circ}$. Elogia asimismo la propiedad de escenarios y atrezzo.

99 Ocupan nada menos que catorce páginas de la Relación, 28 vํ. 34 rº.

100 Viera y Clavijo, op. cit., págs. 20-21; 28, 35, 36-41.

101 Tampoco regatea elogios a la propiedad con que estos pusieron las suyas en escena, autores $y$ actores.
} 
1. ${ }^{a}$ En Canarias, y por lo que toca a lo esencial de las fiestas conmemorativas ordenadas y en loor de la Monarquía, se sigue la liturgia habitual de los centros urbanos peninsulares, e incluso en los iberoaméricanos.

2. a También en las Islas se observa a lo largo del mil setecientos una evolución paralela a la del resto del reino en cuanto al tránsito de la festividad barroca a otra sensibilidad más en consonancia con el espíritu ilustrado y/o del despotismo ilustrado.

3. ․ En las cabeceras del Archipiélago, sin embargo, son detectables una larga serie de peculiaridades en sintonía con sus signos de identidad. Éstos en dependencia de su estructura archipielágica atlántica; su situación y consecuentes vicisitudes, como la lejanía y aislamiento; los factores que facilitaron su desarrollo económico o lo bloqueaban, la presencia del mundo rural en una sociedad demográficamente agraria, e incluso la significación indiana como promotora de su riqueza o acogida durante las crisis económicas, que no faltaron, incluso de muy larga duración. 